\title{
The Role of Manganese in Growth and Sporulation of Bacillus subtilis
}

\author{
By N. VASANTHA AND ERNST FREESE \\ Laboratory of Molecular Biology, National Institute of Neurological and \\ Communicative Disorders and Stroke, National Institutes of Health, \\ Bethesda, Maryland 20205, U.S.A.
}

(Received 25 November 1978)

\begin{abstract}
Phosphoglycerate phosphomutase of Bacillus subtilis, Bacillus cereus and Bacillus megaterium required $\mathrm{Mn}^{2+}$ as cofactor, whereas the wheat germ and rabbit liver enzymes did not. In the absence of $\mathrm{Mn}^{2+}$, B. subtilis did not sporulate in normal sporulation media but it did sporulate if the proper ratio of glucose or glycerol and malate was used. Decoyinine, an inhibitor of guanosine monophosphate synthesis, induced sporulation in the presence of excess glucose and malate to the same extent with and without $\mathrm{Mn}^{2+}$. Apparently, phosphoglycerate phosphomutase is the only strictly $\mathrm{Mn}^{2+}$-requiring enzyme needed for optimal sporulation in normal sporulation media.
\end{abstract}

\section{INTRODUCTION}

Manganese ions are essential for endospore formation in bacilli (Charney et al., 1951). In the absence of $\mathrm{Mn}^{2+}$, rapidly metabolizable carbohydrates, such as glucose and glycerol, are not completely metabolized by Bacillus subtilis and the bacteria accumulate 3-phosphoglyceric acid (3-PGA) (Oh \& Freese, 1976). This results from the strict $\mathrm{Mn}^{2+}$ requirement of phosphoglycerate phosphomutase (EC 5.4.2.1; PGA-mutase) demonstrated both in crude bacterial extracts (Oh \& Freese, 1976) and in pure PGA-mutase of B. subtilis (Watabe \& Freese, 1979). Whether, in addition to PGA-mutase, some other reaction essential for sporulation specifically requires $\mathrm{Mn}^{2+}$ is so far unknown. This paper demonstrates that sporulation of $B$. subtilis can be restored in the absence of $\mathrm{Mn}^{2+}$ by the proper supply and balance of carbon compounds entering the metabolic pathways above and below the PGAmutase reaction. It is also possible to induce sporulation in a medium containing excess of both glucose and malate by adding Decoyinine (Mitani et al., 1977), an inhibitor of guanosine monophosphate synthetase; when Decoyinine is added while the culture has a sufficiently low cell titre (i.e. has not accumulated too much 3-PGA), the same extent of sporulation is observed in the presence and the absence of $\mathrm{Mn}^{2+}$.

\section{METHODS}

Bacteria and growth. The principal strain used was 60015 (metC trpC), a transformable derivative of $B$. subtilis 168. Eacillus megaterium 80013 (ATCC 19243) and Bacillus cereus 80001 were used for comparison of $\mathrm{Mn}^{2+}$ requirements.

Nutrient sporulation medium (NSMP) contained nutrient broth (Difco) at $8 \mathrm{~g} \mathrm{l}^{-1}$ (autoclaved) and sterile additions of $\mathrm{K}_{2} \mathrm{HPO}_{4} / \mathrm{KH}_{2} \mathrm{PO}_{4}\left(10 \mathrm{~mm}-\mathrm{P}_{\mathrm{i}}, \mathrm{pH} 6.5\right), 1 \mathrm{mM}-\mathrm{MgCl}_{2}, 0.7 \mathrm{mM}-\mathrm{CaCl}_{2}, 50 \mu \mathrm{M}-\mathrm{MnCl}_{2}, 1 \mu \mathrm{M}-\mathrm{FeCl}_{3}$, $25 \mu \mathrm{g} \mathrm{L}$-tryptophan $\mathrm{ml}^{-1}$ and $10 \mu \mathrm{g} \mathrm{L}-$ methionine $\mathrm{ml}^{-1}$. For some experiments $\mathrm{MnCl}_{2}$ was omitted (NSMP$\left.\mathrm{Mn}^{2+}\right)$.

Synthetic growth medium contained $\mathrm{KH}_{2} \mathrm{PO}_{4} / \mathrm{K}_{2} \mathrm{HPO}_{4}\left(10 \mathrm{~mm}-\mathrm{P}_{\mathrm{i}}\right.$, pH 7.0), $10 \mathrm{~mm}-\left(\mathrm{NH}_{4}\right)_{2} \mathrm{SO}_{4}, 5 \mu_{\mathrm{M}-}$ $\mathrm{FeCl}_{3}, 1 \mu \mathrm{M}-\mathrm{ZnCl}_{2}$ and $\mathrm{Mg}^{2+}, \mathrm{Ca}^{2+}, \mathrm{Mn}^{2+}$, tryptophan and methionine as in NSMP, with glucose, glycerol or potassium L-malate (adjusted to $\mathrm{pH} 7 \cdot 0$ with $\mathrm{KOH}$ ) as stated. 
Cultures were grown overnight on plates of tryptose blood agar base (Difco; $33 \mathrm{~g} \mathrm{l}^{-1}$ ) and inoculated into medium to give an $A_{600}$ of 0.05 to 0.1 . The flasks, containing medium that comprised less than $20 \%$ of their volume, were shaken at 120 strokes $\min ^{-1}$ at $37{ }^{\circ} \mathrm{C}$. Growth was followed turbidimetrically at $600 \mathrm{~nm}$. The viable cell count was determined by diluting samples in $\mathrm{KH}_{2} \mathrm{PO}_{4} / \mathrm{K}_{2} \mathrm{HPO}_{4}(100 \mathrm{mM}-\mathrm{P}$, $\mathrm{pH} 7 \cdot 0)$ containing $1 \mathrm{mM}-\mathrm{MgCl}_{2}$ and plating on tryptose blood agar plates. The dilution tubes were then heated for $15 \mathrm{~min}$ at $75^{\circ} \mathrm{C}$, and samples were plated on tryptose blood agar to determine the number of heat-resistant colonyforming units (spores). The plates were incubated for $16 \mathrm{~h}$ at $37^{\circ} \mathrm{C}$ before colonies were counted.

For sporulation, a synthetic sporulation medium was used which contained $\mathrm{KH}_{2} \mathrm{PO}_{4} / \mathrm{K}_{2} \mathrm{HPO}_{4}\left(5 \mathrm{~mm}-\mathrm{P}_{\mathrm{i}}\right.$, pH 7.0), $10 \mathrm{mM}-\left(\mathrm{NH}_{4}\right)_{2} \mathrm{SO}_{4}, 100 \mathrm{~mm}-3$-( $N$-morpholino)propanesulphonic acid (MOPS; adjusted to $\mathrm{pH} 7 \cdot 0$ with $\mathrm{KOH}$ ), $20 \mathrm{mM}$-sodium glutamate (pH 7.0), $2 \mathrm{mM}-\mathrm{MgCl}_{2}, 0.7 \mathrm{mM}-\mathrm{CaCl}_{2}, 50 \mu \mathrm{M}-\mathrm{MnCl}_{2}, 5 \mu \mathrm{M}-\mathrm{FeCl}_{3}$, $1 \mu \mathrm{M}-\mathrm{ZnCl}_{2}, 2 \mu \mathrm{M}$-thiamin, $50 \mu \mathrm{g} \mathrm{L}$-tryptophan $\mathrm{ml}^{-1}, 25 \mu \mathrm{g} \mathrm{L}-$ methionine $\mathrm{ml}^{-1}, 100 \mathrm{~mm}$-glucose and $100 \mathrm{~mm}-$ malate (adjusted to $\mathrm{pH} 7 \cdot 0$ with $\mathrm{KOH}$ ). Where stated, $\mathrm{Mn}^{2+}$ was omitted from the medium.

$\mathrm{Mn}^{2+}$ assay. $\mathrm{Mn}^{2+}$ was determined by atomic absorption in a graphite furnace using a manganese lamp at $403 \mathrm{~nm}$ (Perkin Elmer). Media without added $\mathrm{Mn}^{2+}$ usually contained less than $80 \mathrm{~nm}-\mathrm{Mn}^{2+}$. If the $\mathrm{Mn}^{2+}$ concentration was higher than this, the medium was discarded.

3-Phosphoglycerate (PGA) accumulation. Strain 60015 was grown in NSMP containing $25 \mathrm{~mm}$-glycerol and ${ }^{32} \mathrm{P}_{\mathrm{i}}\left(0 \cdot 3 \mu \mathrm{Ci} \mu \mathrm{mol}^{-1}\right)$. Bacteria from a $5 \mathrm{ml}$ sample were collected on a membrane filter (pore size $0.45 \mu \mathrm{m}$ ), the filter was immediately transferred to a small Petri plate containing $0.5 \mathrm{ml}$ ice-cold $0.5 \mathrm{M}$-formic acid and left on ice for $30 \mathrm{~min}$. After centrifugation of this extract, $5 \mu \mathrm{l}$ of the supernatant were chromatographed on a thin-layer plate containing polyethylene-impregnated cellulose as previously described (Oh \& Freese, 1976).

Induction of sporulation. Strain 60015 was grown in synthetic sporulation medium to an $A_{600}$ of 0.2. The culture was rapidly filtered through a membrane and the bacteria were resuspended in fresh prewarmed medium to give an $A_{600}$ of 0.005 . This culture was shaken at $37^{\circ} \mathrm{C}$ and, at intervals, $20 \mathrm{ml}$ portions were filtered and the bacteria were resuspended in fresh prewarmed medium to give the same $A_{600}$ (as at the time of withdrawal). Three $5 \mathrm{ml}$ samples of each portion were added to three prewarmed $(25 \mathrm{~mm} \mathrm{diam}$.) tubes, one containing Decoyinine $\left(150 \mu \mathrm{g} \mathrm{ml}^{-1}\right)$, another containing Decoyinine and $\mathrm{MnCl}_{2}(50 \mu \mathrm{M})$, and the third containing no addition. The tubes were rapidly shaken $\left(120\right.$ strokes $\left.\mathrm{min}^{-1}\right)$ and growth was followed turbidimetrically by taking $0.5 \mathrm{ml}$ samples, if necessary diluting them in phosphate $/ \mathrm{Mg}^{2+}$ buffer so that the $A_{600}$ was less than $0 \cdot 8$. The titres of viable cells and heat-resistant spores were determined $10 \mathrm{~h}$ after transfer of the cells to the tubes. Decoyinine was a kind gift from Dr G. B. Whitfield of the Upjohn Co., Kalamazoo, Michigan, U.S.A.

Preparation of cell extracts for PGA-mutase assay.

(i) Bacilli. Bacillus megaterium was grown in NSMP to an $A_{600}$ of $1 \cdot 0$, centrifuged $\left(4^{\circ} \mathrm{C}, 12000 \mathrm{~g}\right.$ ), washed twice with $10 \mathrm{~mm}-N$-2-hydroxyethylpiperazine- $N^{\prime}$-2-ethanesulphonic acid (HEPES: adjusted to $\mathrm{pH} 7 \cdot 6$ with $\mathrm{KOH}$ ) containing $2 \mathrm{mM}$-mercaptoethanol and $0.5 \mathrm{mM}-\mathrm{MnCl}_{2}$, suspended at an $A_{600}$ of 30 in similar buffer, and treated with lysozyme $\left(150 \mu \mathrm{g} \mathrm{ml}^{-1}\right)$ for $20 \mathrm{~min}$ at $37^{\circ} \mathrm{C}$. The lysed preparation was centrifuged $\left(4^{\circ} \mathrm{C}\right.$, $35000 \mathrm{~g}$ ) for $20 \mathrm{~min}$. Ammonium sulphate was added to the supernatant to give $61 \%$ saturation at $4{ }^{\circ} \mathrm{C}$. After $30 \mathrm{~min}$, the precipitate was collected and dissolved in $5 \mathrm{ml} \mathrm{HEPES} / \mathrm{mercaptoethanol} / \mathrm{MnCl}_{2}$ buffer, and $1 \mathrm{ml}$ portions were dialysed overnight with constant stirring against $500 \mathrm{ml}$ of either HEPES/mercaptoethanol, or similar buffer containing $10 \mathrm{~mm}$-EDTA and $0.5 \mathrm{mM}-\mathrm{MnCl}_{2}$, or HEPES/mercaptoethanol containing $0.5 \mathrm{mM}-\mathrm{MnCl}_{2}$; each buffer was changed twice. The PGA-mutase activity of the dialysed material was assayed by following the oxidation of NADH at $340 \mathrm{~nm}$. The assay mixture, in $1 \mathrm{ml}$, contained $50 \mathrm{~mm}$ $\mathrm{K}^{+}, N$-tris(hydroxymethyl)methyl-2-aminoethanesulphonic acid (TES) buffer (pH 7.6), $5 \mathrm{mM}-\mathrm{MgCl}_{2}$, $50 \mathrm{~mm}-\mathrm{KCl}, 1 \mathrm{~mm}-\mathrm{MnCl}_{2}, 1 \mathrm{~mm}-\mathrm{ADP}, 0.15 \mathrm{~mm}-\mathrm{NADH}, 1.5$ units enolase, 1.5 units pyruvate kinase, 2.0 units lactate dehydrogenase and $5 \mathrm{~mm}-3$-PGA. Protein concentrations were determined according to Lowry et al. (1951). The PGA-mutase from B. cereus was isolated and assayed according to the same procedure.

(ii) Wheat germ. Wheat germs $(5 \mathrm{~g})$ were suspended in $25 \mathrm{ml}$ ice-cold HEPES/mercaptoethanol/ $\mathrm{MnCl}_{2}$ buffer, ground in a mortar and homogenized for $30 \mathrm{~s}$. The homogenate was centrifuged at $35000 \mathrm{~g}$ for $20 \mathrm{~min}$ and, to the supernatant, $\left(\mathrm{NH}_{4}\right)_{2} \mathrm{SO}_{4}$ was added to give $61 \%$ saturation in the cold. The precipitate was resuspended and portions were dialysed and then assayed as described for the B. megaterium enzyme.

(iii) Rabbit liver. Fresh rabbit liver ( $5 \mathrm{~g}$ ) was minced using scissors in ice-cold HEPES/mercaptoethanol/ $\mathrm{MnCl}_{2}$ buffer containing $0.25 \mathrm{M}$-sucrose. The cells were broken in a homogenizer, the homogenate was was centrifuged at $600 \mathrm{~g}$ for $5 \mathrm{~min}$ and the supernatant was recentrifuged at $35000 \mathrm{~g}$ for $15 \mathrm{~min}$. A $61 \%$ $\left(\mathrm{NH}_{4}\right)_{2} \mathrm{SO}_{4}$ fraction of the supernatant was prepared and processed as described for the B. megaterium enzyme. The PGA-mutase was assayed in the presence of 4 mM-2,3-diphosphoglycerate. 


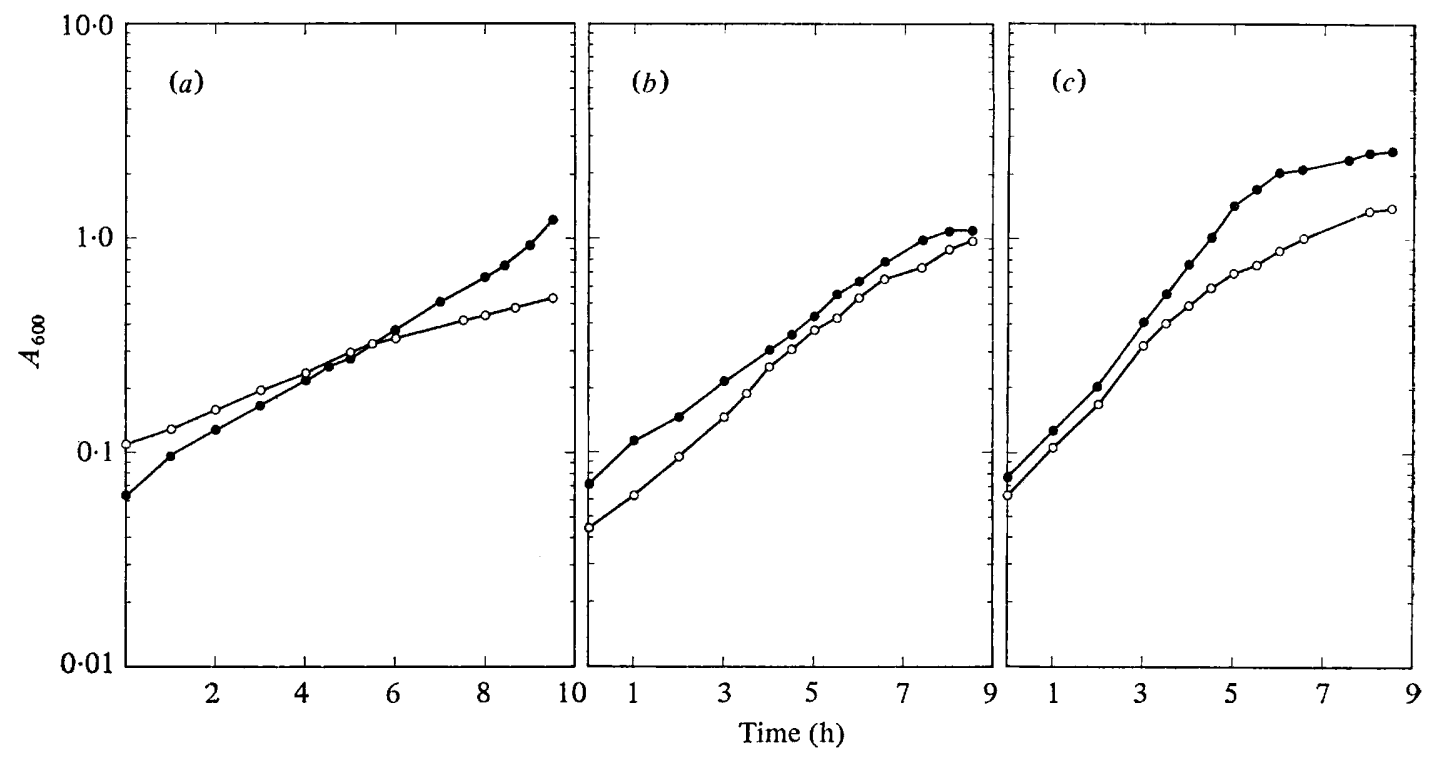

Fig. 1. Growth of strain 60015 in minimal medium containing different carbohydrates with (๑) or without (O) $50 \mu \mathrm{M}-\mathrm{MnCl}_{2}$. (a) Minimal medium with $25 \mathrm{~mm}$-glucose; (b) minimal medium with $50 \mathrm{~mm}$-malate (adjusted to $\mathrm{pH} 7.0$ with $\mathrm{KOH}$ ); $(c)$ minimal medium with both glucose and malate.

\section{RESULTS}

In synthetic medium with malate as sole carbon source, strain 60015 grew at the same rate in the presence and absence of $\mathrm{Mn}^{2+}$ (Fig. $1 \mathrm{~b}$ ). With glucose as sole carbon source, the bacteria grew faster with $\mathrm{Mn}^{2+}$ (doubling time $135 \mathrm{~min}$ ) than without it (doubling time $235 \mathrm{~min}$ ) (Fig. 1a). With glucose and malate together, the initial growth rate was the same with and without $\mathrm{Mn}^{2+}$, up to an $A_{600}$ of $0 \cdot 4$, but subsequently the growth rate without $\mathrm{Mn}^{2+}$ steadily decreased (Fig. 1c); this suggested that a growth inhibitor (3-PGA) was accumulating in the $\mathrm{Mn}^{2+}$-deficient culture, as had previously been observed in $\mathrm{Mn}^{2+}$ deficient nutrient sporulation medium (NSMP $-\mathrm{Mn}^{2+}$ ) containing glucose (Oh \& Freese, 1976).

In NSMP $-\mathrm{Mn}^{2+}$ without any additional carbon source, the bacteria sporulated reasonably well. Addition of malate $(10 \mathrm{~mm})$ did not significantly affect the extent of sporulation (Fig. 2). However, glycerol ( $\geqslant 1 \mathrm{mM}$ ) or glucose ( $>2 \mathrm{~mm}$ ) significantly reduced sporulation (Fig. 2). In this case the spore titre increased with the concentration of added $\mathrm{Mn}^{2+}$, reaching a maximum of $5 \times 10^{8}$ to $7 \times 10^{8}$ spores $\mathrm{ml}^{-1}(0.62$ to 0.87 spores per viable cell $)$ at $1 \mu \mathrm{M}-$ $\mathrm{Mn}^{2+}$, or higher if the medium contained $5 \mathrm{~mm}$-glucose or glycerol at the beginning (results not shown). The adverse effect of glucose or glycerol could also be counteracted by malate. For example, in NSMP- $\mathrm{Mn}^{2+}$ containing $2.5 \mathrm{mM}$-glycerol (or glucose) the spore titre increased with the malate concentration to a maximum at $15 \mathrm{~mm}$ (Fig. $3 \mathrm{a}$ ). Conversely, if the initial malate concentration was $10 \mathrm{~mm}$ the spore titre decreased with increasing concentration of glucose (Fig. $3 b$ ) or glycerol (not shown).

The presence of glucose or glycerol resulted in the accumulation of 3-PGA (Fig. 4) causing the arrest of growth at the low $A_{600}$ value of 1 . When malate was added to such a culture, growth resumed and the intracellular concentration of 3-PGA decreased, and then increased later when a new plateau of growth was reached (Fig. 4). 
Malate added (mM)

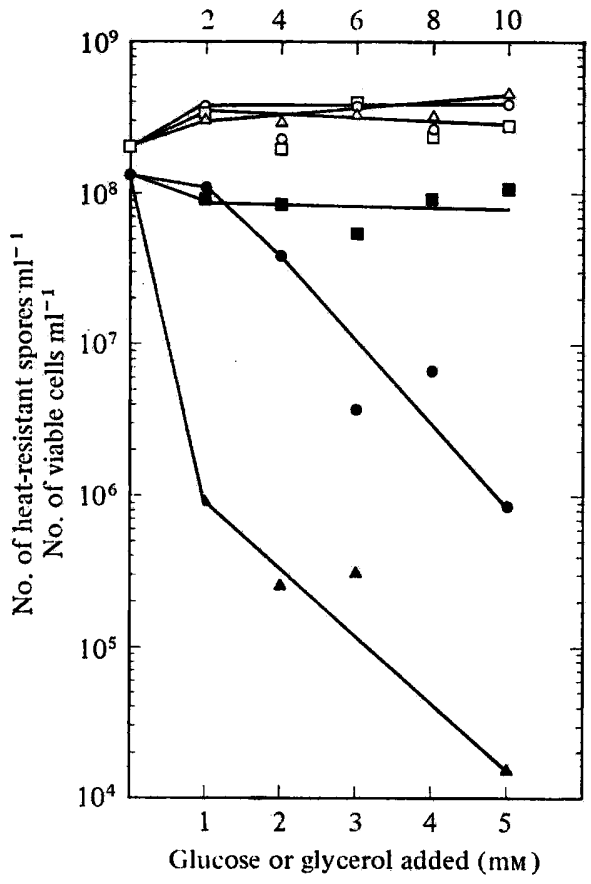

Fig. 2. Effect of carbohydrates on sporulation in the absence of $\mathrm{Mn}^{2+}$. Strain 60015 was grown in NSMP $-\mathrm{Mn}^{2+}$ containing either glucose $(O, O)$ or glycerol $(\triangle, \Delta)$ or potassium malate (adjusted to $\mathrm{pH} 7.0$ with $\mathrm{KOH})(\square, \boldsymbol{\square})$. The viable bacterial titre $(O, \Delta, \square)$ and spore titre $(\mathbf{O}, \boldsymbol{\Delta}, \boldsymbol{\square})$ were determined after $18 \mathrm{~h}$.

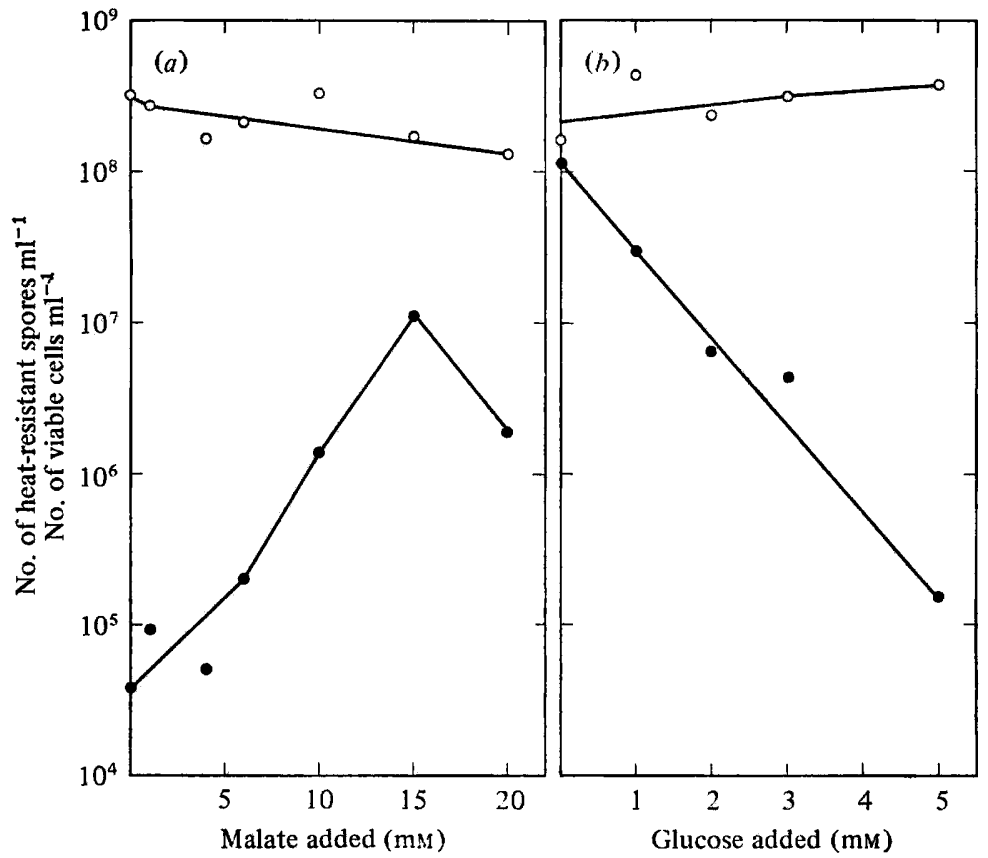

Fig. 3. Restoration of sporulation by malate and suppression by glucose in the absence of $\mathrm{Mn}^{2+}$. Strain 60015 was grown in NSMP- $\mathrm{Mn}^{2+}$ containing (a) $2.5 \mathrm{mM}$-glycerol and different amounts of malate (2 to $20 \mathrm{~mm}$ ) or (b) $10 \mathrm{~mm}$-potassium malate (adjusted to pH 7.0 with $\mathrm{KOH}$ ) and different amounts of glucose (1 to $5 \mathrm{~mm}$ ). The total viable bacterial titre $(O)$ and the spore titre $(\bigcirc)$ were determined after $18 \mathrm{~h}$. 


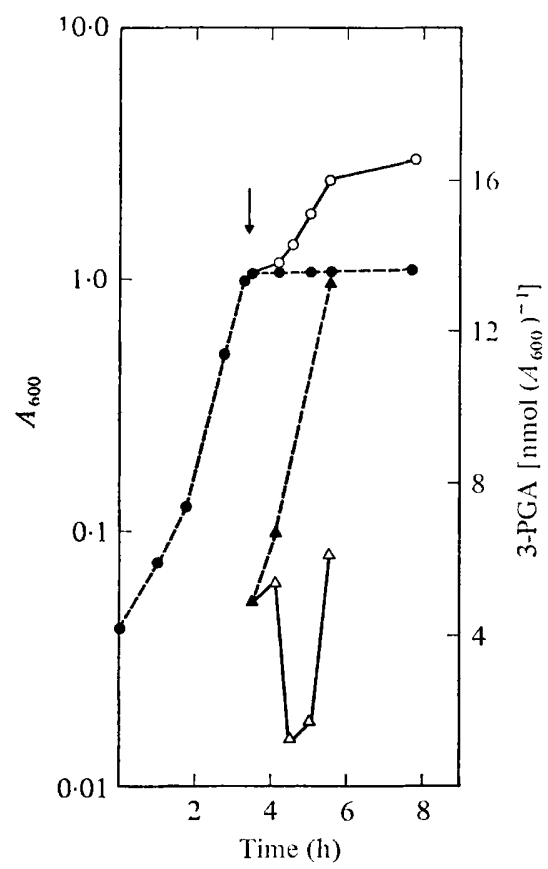

Fig. 4. Inhibition of growth in the absence of $\mathrm{Mn}^{2+}$ by 3-PGA accumulation and restoration by malate. Strain 60015 was grown in NSMP $-\mathrm{Mn}^{2+}$ containing $25 \mathrm{mM}$-glycerol and ${ }^{32} \mathrm{P}_{1}(0 \cdot 3 \mu \mathrm{Ci}$ $\left.\mu \mathrm{mol}^{-1}\right)$. At the time indicated by the arrow, $50 \mathrm{~mm}$-potassium malate was added. At different times, the bacteria from $5 \mathrm{ml}$ samples were collected on membrane filters (pore size $0.45 \mu \mathrm{m}$ ) and extracted with ice-cold $0.5 \mathrm{M}$-formic acid. Portions $(5 \mu \mathrm{l})$ of the extracts were chromatographed and 3-PGA was determined as described in Methods. $A_{600}$ of culture without malate addition; $O$, $A_{600}$ after malate addition. $\triangle, 3-P G A$ concentration in culture without malate addition; $\triangle, 3-P G A$ concentration after malate addition.

\section{Induction of sporulation by Decoyinine in the absence of $\mathrm{Mn}^{2+}$}

The above results suggested that $\mathrm{Mn}^{2+}$ was needed for sporulation mainly because it had to activate PGA-mutase thereby preventing the accumulation of the inhibitory 3-PGA and assuring the supply of carbon compounds in both parts of the metabolic pathways interconnected by PGA-mutase. If that were correct, it should be possible to induce sporulation in the presence of excess glucose and malate by Decoyinine, irrespective of the presence or absence of $\mathrm{Mn}^{2+}$. To be successful, Decoyinine would probably have to be added before too much 3-PGA had accumulated. This experiment was performed in synthetic sporulation medium in which significant growth inhibition due to deficiency of $\mathrm{Mn}^{2+}$ was observed when the $A_{600}$ increased beyond $0 \cdot 6$ (Fig. 5a). When Decoyinine $\left(150 \mu \mathrm{g} \mathrm{ml}^{-1}\right)$ was added to such cultures and sporulation was measured $10 \mathrm{~h}$ later, excellent sporulation was observed for cultures having $A_{600}$ values of 0.3 to 0.5 whereas much lower spore titres (and long cell filaments) were obtained when Decoyinine was added to cultures with $A_{600}$ values above $0 \cdot 7$ (Fig. $5 b$ ). In contrast, the cultures containing $\mathrm{Mn}^{2+}$ produced good sporulation for a wider $A_{600}$ range as they did not accumulate the inhibitory 3-PGA.

\section{$\mathrm{Mn}^{2+}$ requirement of the PGA-mutase of other organisms}

Ammonium sulphate precipitates of cell-free extracts, assayed after dialysis against a buffer containing $\mathrm{Mn}^{2+}$ or $\mathrm{Mn}^{2+}$ and EDTA, demonstrated that the PGA-mutases of $B$. megaterium and $B$. cereus also required $\mathrm{Mn}^{2+}$ whereas that of wheat germ did not and that of rabbit liver required 2,3-diphosphoglycerate (Table 1). On dialysis in the absence of $\mathrm{Mn}^{2+}$ 

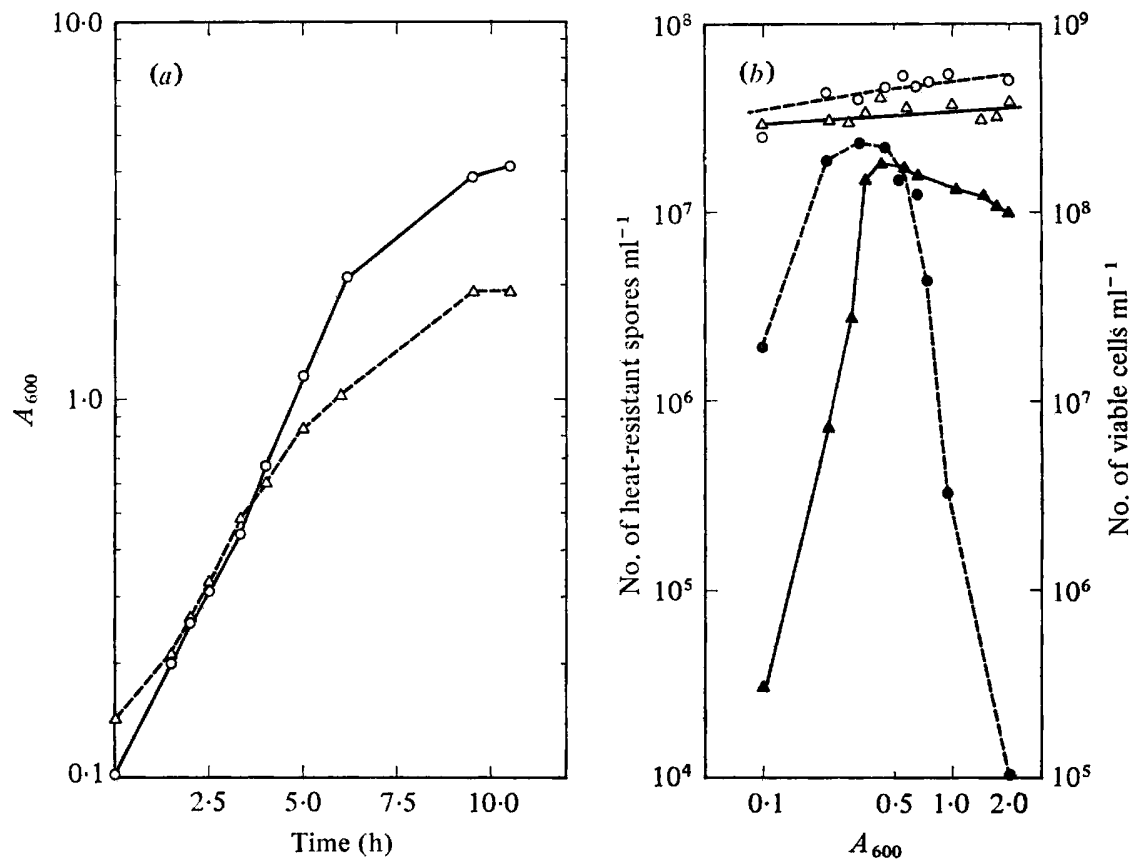

Fig. 5. Induction of sporulation by Decoyinine in the presence or absence of $\mathrm{Mn}^{2+}$. Strain 60015 was grown in the presence (-) or absence (-- ) of $\mathrm{Mn}^{2+}$ in synthetic sporulation medium. Decoyinine $\left(150 \mu \mathrm{g} \mathrm{ml}^{-1}\right)$ was added at different times, and the viable bacterial titre and spore titre were determined $10 \mathrm{~h}$ after the addition of drug. $(a) A_{600}$ in the presence $(O)$ and absence $(\triangle)$ of $\mathrm{Mn}^{2+}$. (b) Spore titre (O) and viable bacterial titre $(O)$ in the absence of $\mathbf{M n}^{2+}$; spore titre $(\boldsymbol{A})$ and viable bacterial titre $(\triangle)$ in the presence of $\mathrm{Mn}^{2+}$.

\section{Table 1. Effect of $\mathrm{Mn}^{2+}$ on phosphoglycerate phosphomutase activity}

PGA-mutase was isolated and assayed as described in Methods. The $61 \%\left(\mathrm{NH}_{4}\right)_{2} \mathrm{SO}_{4}$ fraction was divided into three portions and dialysed against 10 mM-HEPES pH 7.6 containing 2 mM- $\beta$ mercaptoethanol and either (i) $0.5 \mathrm{~mm}-\mathrm{MnCl}_{2}\left(+\mathrm{Mn}^{2+}\right)$, (ii) no addition $\left(-\mathrm{Mn}^{2+}\right.$ ) or (iii) both 0.5 mM- $\mathrm{MnCl}_{2}$ and $10 \mathrm{mM}-E D T A\left(+\mathrm{Mn}^{2+}+\right.$ EDTA). Enzyme activities were determined as $\mu \mathrm{mol}$ 3-PGA converted $\mathrm{min}^{-1}$ (mg protein) ${ }^{-1}$, and the results show the percentage of activity remaining after dialysis against the various HEPES/mercaptoethanol buffers.

Source of

PGA-mutase

B. megaterium

B. cereus

Wheat germ

Rabbit liver*
Activity remaining (\%) after dialysis

$\begin{array}{ccc}+\mathrm{Mn}^{2+} & -\mathrm{Mn}^{2+} & +\mathrm{Mn}^{2+}+\text { EDTA } \\ 96 & 6 & 18 \\ 102 & 9 & 17 \\ 98 & 84 & 127 \\ 106 & 108 & 111\end{array}$

* The enzyme isolated from rabbit liver was assayed in the presence of 4 mm-2,3-diphosphoglycerate.

or in the presence of $\mathrm{Mn}^{2+}$ and EDTA, the PGA-mutase activities of Bacillus extracts were irreversibly lost whereas those of wheat germ and rabbit liver were not. Thus the $\mathrm{Mn}^{2+}$ requirement of PGA-mutase seems to be characteristic of the genus Bacillus.

\section{DISCUSSION}

The metabolic processes leading to endospore formation depend on the establishment of a proper balance between the concentrations of intracellular metabolites. If this balance is 
disturbed, either by inhibition of an enzyme or by mutation, sporulation remains suppressed (Freese et al., 1974). Such an imbalance is produced by deficiency of $\mathrm{Mn}^{2+}$ in bacilli where it results in an inactive PGA-mutase. In B. subtilis, the physiological effect of this deficiency is similar to that of a mutation in phosphoglycerate kinase. In both cases the overall metabolic pathways are divided into two parts, and the ratio of carbon compounds entering each part determines whether the cell can differentiate, or whether it accumulates a compound which suppresses sporulation (Freese et al., 1972; Oh \& Freese, 1976). The ability of the tricarboxylic acid cycle to convert carbon compounds into $\mathrm{CO}_{2}$ allows the efficient elimination of compounds (such as malate) entering this portion of the metabolic pathway system. In the absence of $\mathrm{Mn}^{2+}$, the proper ratio of malate to glucose allows complete consumption of glucose towards the end of growth, without excess accumulation of 3-PGA, and thus allows initiation of sporulation which can be completed because just sufficient (glucosederived) intermediates are present to enable the required synthesis of membrane and peptidoglycans.

Sporulation can be induced in the presence of excess carbohydrates by Decoyinine, irrespective of the presence or absence of $\mathrm{Mn}^{2+}$. Decoyinine has only to be added before 3-PGA has reached a concentration at which it suppresses sporulation. The induction of sporulation demonstrates that in the presence of Decoyinine, where certain metabolic reactions (tricarboxylic acid cycle, gluconeogenesis, etc.) are no longer needed for sporulation (Freese et al., 1977), no $\mathrm{Mn}^{2+}$-requiring reaction is needed for sporulation. This indicates that under normal sporulation conditions (without Decoyinine) the only reactions which specifically require $\mathrm{Mn}^{2+}$ are those which are not needed in the presence of Decoyinine. Only two such reactions are known. One is PGA-mutase and the other is fructose-1,6-bisphosphatase, the strict $\mathrm{Mn}^{2+}$ requirement of which has been demonstrated in B. licheniformis (Opheim \& Bernlohr, 1975) and in B. subtilis (Y. Fujita \& E. Freese, unpublished results). A mutant lacking all fructose-1,6-bisphosphatase activity has been isolated in our laboratory; in nutrient sporulation medium, this strain can sporulate as well as the parent strain (unpublished results). Akrigg \& Mandelstam (1978) and Akrigg (1978) have recently reported the formation (after stage II of sporulation) of an extracellular $\mathrm{Mn}^{2+}$ stimulated deoxyribonuclease which requires $10 \mathrm{~mm}-\mathrm{Mn}^{2+}$ for optimal activity and has $15 \%$ of this activity if $\mathrm{Mn}^{2+}$ is replaced by $\mathrm{Mg}^{2+}$. This enzyme is either not needed for sporulation in the presence of Decoyinine or its $\mathrm{Mg}^{2+}$ activation suffices. Thus it appears likely that the strict $\mathrm{Mn}^{2+}$ requirement observed for Bacillus sporulation results exclusively from the $\mathrm{Mn}^{2+}$ requirement of PGA-mutase.

\section{REFERENCES}

AKrIGg, A. (1978). Purification and properties of a manganese-stimulated deoxyribonuclease produced during sporulation of Bacillus subtilis. Biochemical Journal 172, 69-76.

Akrigg, A. \& Mandelstam, J. (1978). Extracellular manganese-stimulated deoxyribonuclease as a marker event in sporulation of Bacillus subtilis. Biochemical Journal 172, 63-67.

Charney, J., Fisher, W. P. \& Hegarty, C. P. (1951). Manganese as an essential element for sporulation in the genus Bacillus. Journal of Bacteriology 62, 145-148.

Freese, E., OH, Y. K., Freese, E. B., Diesterhaft, M. D. \& Prasad, C. (1972). Suppression of sporulation of Bacillus subtilis. In Spores V, pp. 212-221. Edited by H. O. Halvorson, R. Hanson \& L. L. Campbell. Washington, D.C.: American Society for Microbiology.

Freese, E., Ichikawa, T., Oh, Y. K., Freese, E. B.
\& Prasad, C. (1974). Deficiencies or excesses of metabolites interfering with differentiation. Proceedings of the National Academy of Sciences of the United States of America 71, 4188-4193.

Freese, E., Heinze, J., Mitani, T. \& Freese, E. B. (1977). Limitation of nucleotides induces sporulation. In Spores VII, pp. 277-285. Edited by G. Chambliss \& J. C. Vary. Washington, D.C.: American Society for Microbiology.

Lowry, O. H., Rosebrough, N. J., Farr, A. L. \& RANDALL, R. J. (1951). Protein measurement with the Folin phenol reagent. Journal of Biological Chemistry 193, 265-275.

Mitani, T., Heinze, J. \& Freese, E. (1977). Induction of sporulation in Bacillus subtilis by decoyinine or hadacidin. Biochemical and Biophysical Research Communications 77, 1118-1125.

OH, Y. K. \& FrEESE, E. (1976). Manganese requirement of phosphoglycerate phosphomutase and its 
consequences for growth and sporulation of Bacillus subtilis. Journal of Bacteriology 127, 739746.

Opheim, D. J. \& Bernlohr, R. W. (1975). Purification and regulation of fructose-1,6-bisphosphatase from Bacillus licheniformis. Journal of
Biological Chemistry 250, 3024-3033.

Watabe, K. \& Freese, E. (1979). Purification and properties of the manganese dependent phosphoglycerate mutase of Bacillus subtilis. Journal of Bacteriology 137, 773-778. 